DOI: 10.17707/AgricultForest.63.1.32

\author{
Anto MIJIĆ, Ivica LIOVIĆ, Aleksandra SUDARIĆ, \\ Drena GADŽO, Zoran JOVOVIĆ, Mirjana JANKULOVSKA, \\ Antonela MARKULJ KULUNDŽIĆ, Tomislav DUVNJAK ${ }^{1}$
}

\title{
THE EFFECT OF ENVIRONMENT ON THE PHENOTYPIC EXPRESSION OF GRAIN YIELD, OIL CONTENT AND OIL YIELD IN SUNFLOWER HYBRIDS
}

\begin{abstract}
SUMMARY
Continuous sunflower breeding work at the Agricultural Institute Osijek results in the creation of new hybrid combinations which are then tested in a network of micro and macro trials. This paper presents the results of the investigation on seven sunflower hybrids: one standard and six new hybrid combinations (OS-H-2 to OS-H-7) from the Agricultural Institute Osijek, in a period of four years (2012-2015) at a location in Osijek. Trials were set as RCBD and the most important sunflower traits were analyzed: grain yield, oil content and oil yield. The results indicate that the values of analyzed traits were significantly impacted by year (and respectively by weather conditions), hybrid and the year $\mathrm{x}$ hybrid interaction. The highest yield was observed in 2013, when grain yield achieved $6.243 \mathrm{t} / \mathrm{ha}$ and oil yield $2.889 \mathrm{t} / \mathrm{ha}$. The highest oil content was recorded in the year $2012(51.35 \%)$. The highest grain yield was achieved by the hybrids OS-H-4 (6.257 t/ha) and OS-H-2 (5.911 t/ha), and oil content by hybrids OS-H-3 (51.83\%) and OS-H-4 (51.62\%). The hybrid OS-H-4 had the highest oil yield (2.944 t/ha), and it can therefore be considered as a promising hybrid for application on the recognition process in the country and abroad.

Keywords: sunflower, hybrid, grain yield, oil content, oil yield.
\end{abstract}

\section{INTRODUCTION}

Sunflower (Helianthus annuus L.) is an extremely important field crop. Primarily, it is grown for oil used in human consumption. Sunflower oil is a valuable source of tocopherols and phytosterols and has a positive impact on human health (Patel and Thompson, 2006, Gotar et al., 2008, Jocković et al., 2014).

It is important as raw material for the processing industry, used as animal feed and in beekeeping. It is grown on about 24 million hectares around the world, with total annual production of about 33 million tons of grain. In the EU,

\footnotetext{
${ }^{1}$ Anto Mijić, Ivica Liović, Aleksandra Sudarić, Antonela Markulj Kulundžić, Tomislav Duvljan Agricultural Institute Osijek, Južno predgrađe 17, 31103, Osijek, CROATIA, Drena Gadžo University of Sarajevo, Faculty of Agriculture and Food Sciences, Zmaja od Bosne 8, 71000, Sarajevo, BOSNIA AND HERZEGOVINA, Zoran Jovović University of Montenegro, Biotehnical faculty, Mihaila Lalića 1, 81000, Podgorica, MONTENEGRO, Mirjana Jankulovska St. Cyril and Methodius University in Skopje, Faculty for Agricultural Sciences and Food, blvd. Aleksandar Makedonski BB 1000 Skopje, MACEDONIA
} 
sunflower production is organized on about 4 million hectares with an average grain yield of $1.37 \mathrm{t} / \mathrm{ha}$. Grain yield in Croatia is at top of the EU (about 2.66 t/ha), and areas of sunflower are approximately 34000 ha (average 2005-2015) (FAOSTAT Database, 2016). The large fluctuations, both in terms of grain yield and in terms of areas of sunflower, should be emphasized (Liović et al., 2006, Mijić et al., 2011).

Higher grain yield, oil content, and oil yield per unit area in a variety of environments are the primary goals of every sunflower producer (Kaya and Kolsarici, 2011, Škorić, 2012). Therefore, these traits are the focus of the majority of sunflower breeders in the world. Grain yield, oil content and oil yield are quantitative traits determined by genetic potential with significant variation influenced by environmental factors. The phenotypic expression of these properties is conditioned by genetic factors, factors from the external environment, as well as their interaction (Krizmanić et al., 2012). The environmental conditions are often a limiting factor in sunflower production (Miklič et al., 2007, Škorić, 2012). The occurrence of drier vegetation season, especially in summer, with less rainfall, higher temperatures, extremely high daily temperature maximums, or fluctuations and weather parameters in the short term (daily, weekly) significantly affects all the living world and consequently field crops. This impact is mostly negative, which is reflected through reduced value of the most important agronomic traits, both in quantitative (grain and oil) and qualitative (oil quality) terms. In addition to the weather conditions, the soil is also an important factor for successful production, as well as the level of applied technology. More intense, more comprehensive technology significantly reduces the negative impact of weather on yield (Pepo and Molnarova, 2010).

The aim of this study was to compare grain yield, oil content and oil yield of seven sunflower hybrids during the period of four years in eastern Croatia, with emphasis on the rainfall impact and mean air temperature and to select the best hybrid combinations for further breeding work and the process of recognition.

\section{MATERIAL AND METHODS}

The basic material in the study included seven sunflower hybrids, out of which six are new hybrid combinations (OS-H-2 to OS-H-7) created at the Agricultural Institute Osijek. An introduced hybrid, which for many years has occupied a large area of sunflower in Croatia, was used as a standard. Hybrids were sown in duration of four years $(2012-2015)$, according to a randomized block design with three replications at the experimental fields of the Agricultural Institute Osijek. The soil is eutric cambisol with good pedodynamic properties, medium supplied with phosphorus and potassium, $\mathrm{pH}$ in $\mathrm{KCl}$ 6.3. Other elements of the experiment were: the length of the basic plot of $5 \mathrm{~m}$, width of the basic plot of $2.8 \mathrm{~m}$, inter row spacing of $0.7 \mathrm{~m}$, space in row $0.23 \mathrm{~m}$, the distance between the blocks $1.5 \mathrm{~m}$, the recommended stand density of 62112 plants per hectare. 
During all years of research the standard agricultural practices were applied. The most important sunflower agronomic traits were analyzed. Grain yield per plot was recalculated per hectare according to the standard (9\% moisture and $2 \%$ impurities). The oil content was determined by the nuclear magnetic resonance method (MQA 7005 NMR Analyser), and the oil yield was calculated based on grain yield and oil content.

The values obtained for individual traits were systematized by hybrids and years and statistically analyzed by the analysis of variance (ANOVA) with the LSD test at level $\mathrm{P}<0.05$. For each hybrid combination minimum and maximum values were calculated and compared to the average of experiments (\%). Analysis of stability was made by means of regression coefficient $\left(b_{i}\right)$ that represents the ratio $\mathrm{k}$ of the genotype according to various environments and deviation from regression $\left(\mathrm{s}^{2} \mathrm{~d}_{\mathrm{i}}\right)$ concerning the unpredictable variability of a part of the genotype was obtained from the sum of squared differences between the expected and the obtained yield (Becker and Leon, 1988).

Table 1: Monthly rainfall $(\mathrm{mm})$ and mean monthly temperatures $\left({ }^{\circ} \mathrm{C}\right)$

\begin{tabular}{|c|c|c|c|c|c|c|c|c|c|}
\hline Year & I-III & IV & V & VI & VII & VIII & IX & Sum \\
\hline \multicolumn{8}{|c|}{ Precipitation $(\mathrm{mm})$} \\
\hline 2012 & 82.6 & 47.3 & 93.5 & 67.9 & 47.8 & 4.0 & 32.3 & 375.4 \\
\hline 2013 & 213.1 & 44.5 & 132.1 & 61.2 & 44.8 & 86.8 & 106.3 & 688.8 \\
\hline 2014 & 109.5 & 67.2 & 142.6 & 63.9 & 68.8 & 69.9 & 74.9 & 596.8 \\
\hline 2015 & 167.9 & 10.6 & 108.6 & 44.9 & 7.6 & 50.8 & 29.1 & 419.5 \\
\hline Average & 143.3 & 42.4 & 119.2 & 59.5 & 42.3 & 52.9 & 60.7 & 520.1 \\
\hline $\begin{array}{c}\text { Average } \\
1961-2014\end{array}$ & 124.9 & 54.2 & 64.8 & 85.3 & 63.4 & 62.1 & 56.1 & 510.8 \\
\hline \multicolumn{8}{|c|}{ Temperature $\left({ }^{\circ} \mathrm{C}\right)$} \\
\hline 2012 & & 12.5 & 16.9 & 22.5 & 24.8 & 24.1 & 18.9 & 19.9 \\
\hline 2013 & & 13.0 & 17.5 & 20.2 & 23.6 & 23.7 & 16.4 & 19.1 \\
\hline 2014 & & 13.5 & 16.4 & 20.8 & 22.2 & 21.2 & 17.4 & 18.6 \\
\hline 2015 & & 12.4 & 17.9 & 21.3 & 24.9 & 24.1 & 19.0 & 19.9 \\
\hline Average & & 12.9 & 17.2 & 21.2 & 23.9 & 23.3 & 17.9 & 19.4 \\
\hline $\begin{array}{c}\text { Average } \\
1961-2014\end{array}$ & 11.7 & 16.8 & 20 & 21.6 & 21 & 16.6 & 18.0 \\
\hline
\end{tabular}

*source: Meteorological and Hydrological Service of the Republic of Croatia

Table 2: Analysis of variance for grain yield, oil content and oil yield

\begin{tabular}{|c|c|c|c|}
\hline \multirow{2}{*}{ Source of variation } & Grain yield & Oil content & Oil yield \\
\cline { 2 - 4 } & $\begin{array}{c}\text { MS } \\
\text { (mean squares) }\end{array}$ & $\begin{array}{c}\text { MS } \\
\text { (mean squares) }\end{array}$ & $\begin{array}{c}\text { MS } \\
\text { (mean squares) }\end{array}$ \\
\hline Hybrid & $1.845^{* *}$ & $26.674^{* *}$ & $0.438^{* *}$ \\
\hline Year & $4.468^{* *}$ & $89.684^{* *}$ & $1.488^{* *}$ \\
\hline Hybrid x Year & $1.020^{*}$ & $4.163^{* *}$ & $0.246^{* *}$ \\
\hline
\end{tabular}

$*$ F test significant on level $\mathrm{P}<0.05$

** $\mathrm{F}$ test significant on level $\mathrm{P}<0.01$ 
The analysis of variance indicated that the hybrid, year and their interaction had a significant impact on the grain yield, oil content and oil yield. It also revealed that the variability of studied traits in some hybrids is derived from the genetic diversity of the material selected for the research, diversity of environments (years) in which the traits were realized, and their interaction as well (Table 2).

\section{Grain yield}

Table 3 shows the average values for grain yield of the hybrids over the years. The highest yield was achieved in 2013 (6.243 t/ha) and the lowest in 2012 (5.193 t/ha). The year with the highest grain yield (2013) was characterized by good reserve of winter moisture (I-III month - $213.1 \mathrm{~mm}$ ), and the total rainfall and its distribution by months and decades during this growing season was exceptionally good. This is in agreement with the research of Gadžo et al., (2011) who pointed out that sunflower crop responds very well to the abundance of accumulated moisture in the soil during winter. Also, the mean monthly temperatures were on the average level and the number of hot days was acceptable (Table 1). The reason for the low grain yield in 2012 is the fact that this was the warmest year during the research period and with higher temperatures compared to the multi-year average. During June, July and August, average monthly temperatures were higher compared to 2013 and 2014, and compared to 2015 this year had many more warm days. It should also be noted that during winter (January to March) the precipitation was only $82.6 \mathrm{~mm}$, and during the growing season (April-September) $292.8 \mathrm{~mm}$, which is considerably less compared to the other years of research and to the multi-year average. In August, at the stage of intensive grain filling, there was only $4 \mathrm{~mm}$ of rainfall. Similar results were presented by Bošnjak (1999) and Josipović and Mađar (2004).

Table 3: Grain yield (t/ha) of analyzed sunflower hybrids and range (\%)

\begin{tabular}{|c|c|c|c|c|c|c|}
\hline Hybrid & 2012 & 2013 & 2014 & 2015 & Average & $\begin{array}{c}\text { Range } \\
(\%)\end{array}$ \\
\hline OS-H-4 & 5.963 & 7.000 & 5.920 & 6.146 & 6.257 & $95-112$ \\
\hline OS-H-2 & 5.660 & 6.075 & 5.798 & 6.111 & 5.911 & $96-103$ \\
\hline STANDARD & 4.253 & 6.795 & 6.184 & 6.399 & 5.908 & $72-115$ \\
\hline OS-H-7 & 5.408 & 6.289 & 5.260 & 6.623 & 5.895 & $89-112$ \\
\hline OS-H-6 & 4.593 & 6.326 & 5.613 & 6.125 & 5.664 & $81-112$ \\
\hline OS-H-5 & 5.819 & 5.855 & 4.800 & 4.967 & 5.360 & $90-109$ \\
\hline OS-H-3 & 4.654 & 5.362 & 4.913 & 5.183 & 5.028 & $93-107$ \\
\hline Average & 5.193 & 6.243 & 5.498 & 5.936 & 5.718 & $91-109$ \\
\hline Min. & 4.253 & 5.362 & 4.800 & 4.967 & 5.028 & \\
\hline Max. & 5.963 & 7.000 & 6.184 & 6.623 & 6.257 & \\
\hline
\end{tabular}

$\mathrm{LSD}_{0.05}$ hybrid (A) 0.567

$\mathrm{LSD}_{0.05}$ year (B) 0.429

$\mathrm{LSD}_{0.05} \mathrm{AxB} 1.134$ 
The experimental hybrid OS-H-4 had an average grain yield of $6.257 \mathrm{t} / \mathrm{ha}$. Also, this hybrid had the highest individual value, and in the most yielding 2013 achieved grain yield of $7.000 \mathrm{t} / \mathrm{ha}$. Another hybrid which also achieved very good results, better than the standard, was OS-H-2 with grain yield of $5.911 \mathrm{t} / \mathrm{ha}$.

The significance of the hybrid $\mathrm{x}$ year interaction indicates that some hybrids are better in wet and others in dry years. The standard hybrid had a grain yield of $4.253 \mathrm{t} / \mathrm{ha}$ in dry year 2012, which was the lowest yield in the experiment. In 2014, with above average rainfall during the growing season, especially in July and August, it was the best hybrid in the trial. The grain yield of this hybrid varied from $72 \%$ to $115 \%$ in relation to the average grain yield (Table 3).

\section{Oil content}

The highest oil content was achieved in the dry 2012 year $(51.35 \%)$ and the lowest in 2014 (47.04\%) (Table 4).

Table 4: Oil content (\%) of analyzed sunflower hybrids and range of variation

\begin{tabular}{|c|c|c|c|c|c|c|}
\hline Hybrid & 2012 & 2013 & 2014 & 2015 & Average & $\begin{array}{c}\text { Range } \\
(\%)\end{array}$ \\
\hline OS-H-3 & 53.69 & 53.31 & 48.73 & 51.59 & 51.83 & $94-104$ \\
\hline OS-H-4 & 53.24 & 53.42 & 47.98 & 51.82 & 51.62 & $93-103$ \\
\hline STANDARD & 51.96 & 51.64 & 47.83 & 50.16 & 50.40 & $95-103$ \\
\hline OS-H-7 & 51.05 & 51.89 & 46.56 & 50.44 & 49.99 & $93-104$ \\
\hline OS-H-5 & 49.90 & 48.96 & 47.61 & 48.73 & 48.80 & $98-102$ \\
\hline OS-H-6 & 49.43 & 47.18 & 47.14 & 48.62 & 48.09 & $98-103$ \\
\hline OS-H-2 & 50.19 & 49.45 & 43.46 & 48.89 & 48.00 & $91-105$ \\
\hline Average & 51.35 & 50.83 & 47.04 & 50.04 & 49.82 & $94-103$ \\
\hline Min. & 49.43 & 47.18 & 43.46 & 48.62 & 48.00 & \\
\hline Max. & 53.69 & 53.42 & 48.73 & 51.82 & 51.83 & \\
\hline
\end{tabular}

$\mathrm{LSD}_{0.05}$ hybrid (A) 0.77

$\mathrm{LSD}_{0.05}$ year (B) 0.59

$\mathrm{LSD}_{0.05} \mathrm{AxB} 1.57$

High values for oil content in 2012 can be explained by the fact that in this year the lowest grain yields and the lowest weight of 1000 grains were registered. A smaller volume of grain means a lower proportion of shell and endosperm in relation to the nucleus, and thus higher oil content. Vranceanu (1977) reported similar results, which explained that increasing the number of plants per unit area resulted in the development of seeds with smaller size, with lower shell relative to the nucleus. Flowering took place in late June and early July, in the period when rainfall was slightly lower, which allowed numerous flights of insects, and thus higher fertilization and higher oil content. Balalić et al. (2008) and Miklič et al. (2014) also point out weather conditions as an important factor in the phenotypic expression of this trait. Sunflower is a typically open pollinated, 
entomophile plant and for higher fertilization insects are extremely important, as confirmed by researches of Waghchoure and Rana (1988) and Puškadija et al. (2009).

During the four-year research, statistically significant higher values of oil content in relation to the standard were found in OS-H-3 (51.83\%) and OS-H-4 hybrid $(51.62 \%)$. The experimental hybrid OS-H-7 had similar values as the standard. These results point to the progress in breeding for this very important sunflower characteristic, and good preconditions for further breeding work in creating high oil sunflower hybrids.

The significance of the hybrid $\mathrm{x}$ year interaction, apart from grain yield, was also established for oil content. The highest variation in relation to the average had OS-H-2 hybrid and the lowest the hybrids OS-H-5 and OS-H-6. The hybrid OS-H-5, which in the rainy year 2014 was the fourth, had significantly worse results in the remaining three years of study. Similar results were observed in the hybrid OS-H-6, which except in 2014 had the lowest value for oil content in all other years.

\section{Oil yield}

The research results in Table 5 indicate that the highest oil yield (2.889 $\mathrm{t} / \mathrm{ha})$ was achieved in 2013, then in 2015 (2.704 t/ha) and in $2012(2.426 \mathrm{t} / \mathrm{ha})$. The lowest oil yield was determined in 2014 (2.352 t/ha). As with grain yield, favorable weather conditions in 2013 had an extremely important role in the expression of this trait. A satisfactory reserve of winter moisture, good distribution of rainfall, a mean monthly temperature and not too high temperature maximums allowed the highest oil yields in this year. This is in agreement with the research of Krizmanić et al. (2013) and Kaya (2016) that highlight the daily mean temperature and moisture level as a significant factor in the determination of this trait.

It should be pointed out that 2012 was a very dry year (in August only 4 $\mathrm{mm}$ of rainfall), characterized by an extreme deficit of rainfall, warm days and shorter vegetation period and grain filling phase. Although the environmental conditions were not so favorable for sunflower growth and development, they did not significantly affect grain and oil yield. It can be said that sunflower, unlike other spring field crops (corn, soybean) significantly reduces the negative effects of stress caused by drought and achieves satisfactory results. The reason lies in the fact that sunflower has a strong root system, but also because of the specific anatomical structure of the stem and leaf. Similar results were reported by Škorić (2009). The significant influence of year on oil yield and also oil content was previously emphasized by Balalić et al. (2007). The experimental hybrid OS-H-4 had the highest oil yield during the research (2.944 t/ha). Also, this hybrid had the highest individual value of $3.403 \mathrm{t} / \mathrm{ha}$ in 2013. The lowest oil yield during the study was detected in the experimental hybrid OS-H-3 (2.372 t/ha). Individually, the hybrid which was used as standard achieved the lowest oil yield (2.011 t/ha) in 2012, but in 2013 was among the best yielding hybrids. 
Table 5: The values of oil yield (t/ha) and range (\%).

\begin{tabular}{|c|c|c|c|c|c|c|}
\hline Hybrid & 2012 & 2013 & 2014 & 2015 & Average & $\begin{array}{c}\text { Range } \\
(\%)\end{array}$ \\
\hline OS-H-4 & 2.889 & 3.403 & 2.585 & 2.898 & 2.944 & $88-116$ \\
\hline STANDARD & 2.011 & 3.193 & 2.692 & 2.921 & 2.704 & $74-118$ \\
\hline OS-H-7 & 2.512 & 2.970 & 2.229 & 3.040 & 2.688 & $83-113$ \\
\hline OS-H-2 & 2.585 & 2.734 & 2.293 & 2.719 & 2.583 & $89-106$ \\
\hline OS-H-6 & 2.066 & 2.716 & 2.408 & 2.710 & 2.475 & $83-110$ \\
\hline OS-H-5 & 2.642 & 2.609 & 2.080 & 2.203 & 2.383 & $87-111$ \\
\hline OS-H-3 & 2.274 & 2.601 & 2.179 & 2.433 & 2.372 & $92-110$ \\
\hline Average & 2.426 & 2.889 & 2.352 & 2.704 & 2.593 & $91-111$ \\
\hline Min. & 2.011 & 2.601 & 2.080 & 2.203 & 2.372 & \\
\hline Max. & 2.889 & 3.403 & 2.692 & 3.040 & 2.944 & \\
\hline
\end{tabular}

$\mathrm{LSD}_{0.05}$ hybrid (A) 0.261

$\mathrm{LSD}_{0.05}$ year $(\mathrm{B}) 0.198$

$\mathrm{LSD}_{0.05} \mathrm{AxB} 0.523$

It can be said that the main goal of every breeder is to increase the genetic potential of the most important agronomic traits, particularly oil yield in case of sunflower. This is a complex trait determined primarily by grain yield components (number of plants per unit area, number of seeds per plant, 1000grain weight, test weight, the proportion of shell, plant height, head diameter, stem diameter) and by length of the growing season, resistance to dominant pathogens, resistance to lodging as well as by oil content in grain. The objective quantification of the expression of this trait should not be guided by the values achieved in certain environments, but by the total value of each cultivar, which allows estimation of stability and adaptability. Thus, in addition to the level of yield in particular environments, the response of the individual genotype (hybrid) to environmental conditions, i.e., genotype by environment interaction is also analyzed, which is the basis for a quantitative assessment of phenotypic stability (Piepho, 1999; Sudarić and Vratarić, 2001).

Based on the statistical parameters like regression coefficient $\left(b_{i}\right)$, deviation from regression $\left(\mathrm{s}^{2} \mathrm{~d}_{\mathrm{i}}\right)$ and the level of oil yield (Table 6), hybrids in the research can be classified into 4 groups:

- The first group $\left(\mathrm{b}_{\mathrm{i}} \approx 1\right.$, and the low value of $\left.\mathrm{s}^{2} \mathrm{~d}_{\mathrm{i}}\right)$ consists of hybrids OS-H-4 (x $\left.=2.944, b_{i}=1.21, \mathrm{~s}^{2} d_{i}=0.04\right)$ and OS-H-6 $\left(x=2.475, b_{i}=0.97, \mathrm{~s}^{2} d_{i}=0.05\right)$. They are stable, widely adaptable hybrids, which would on improved production conditions (higher investment) respond by significant increase of oil yield regardless of environment.

- To the second group belong hybrids that have $b_{i}<1$, and $s^{2} d_{i}>0.00$. These are hybrids that have good performance in low yielding environments, and in high yielding environments achieve small changes in oil yields. We consider them adaptable to low yielding environments. In our research, it is the OS-H-5 hybrid $\left(x=2.383, b_{i}=0.42, \mathrm{~s}^{2} d_{i}=0.11\right)$. 
- The third group includes hybrids which are characterized by values $b_{i}>1$ and $\mathrm{s}^{2} \mathrm{~d}_{\mathrm{i}}>0.00$. The standard hybrid $\left(\mathrm{x}=2.704, \mathrm{~b}_{\mathrm{i}}=1.54, \mathrm{~s}^{2} \mathrm{~d}_{\mathrm{i}}=0.16\right)$ and the hybrid OS-H-7 ( $\left.x=2.688, b_{i}=1.41, \mathrm{~s}^{2} d_{i}=0.09\right)$ belonged to this group. They are adapted to high yielding environments, which means that in low yielding environments they generally have lower oil yields.

- For hybrids OS-H-2 and OS-H-3 it is hard to determine whether they belong to stable or unstable genotypes. For these genotypes the $\mathrm{s}^{2} \mathrm{~d}_{\mathrm{i}}$ parameter value indicates stability, but $b_{i}<1$ indicates unstable genotypes. Therefore, for these genotypes additional evaluation is needed.

Table 6: The average oil yield (2012- 2015), regression coefficient $\left(b_{i}\right)$ and deviation from regression $\left(\mathrm{s}^{2} \mathrm{~d}_{\mathrm{i}}\right)$.

\begin{tabular}{|c|c|c|c|}
\hline Hybrid & $\begin{array}{c}\text { Oil yield } \\
\text { (t/ha) }\end{array}$ & $\mathrm{b}_{\mathrm{i}}$ & $\mathrm{s}^{2} \mathrm{~d}_{\mathrm{i}}$ \\
\hline STANDARD & 2.704 & 1.54 & 0.16 \\
\hline OS-H-2 & 2.583 & 0.70 & 0.02 \\
\hline OS-H-3 & 2.372 & 0.74 & 0.01 \\
\hline OS-H-4 & 2.944 & 1.21 & 0.04 \\
\hline OS-H-5 & 2.383 & 0.42 & 0.11 \\
\hline OS-H-6 & 2.475 & 0.97 & 0.05 \\
\hline OS-H-7 & 2.688 & 1.41 & 0.09 \\
\hline Average & 2.593 & & \\
\hline
\end{tabular}

\section{CONCLUSIONS}

Based on the analyzed data for grain yield, oil content and oil yield in sunflower hybrids the following conclusions can be made:

1. For all studied traits statistically significant differences for years of research, hybrids and hybrid $\mathrm{x}$ year interactions were determined,

2. Satisfactory reserve of winter moisture, good distribution of rainfall and mean monthly temperature, and not too high temperature maximums in 2013 resulted in the highest grain yield (6.243 t/ha) and oil yield (2.889 t/ha),

3 . The highest oil content $(51.35 \%)$ was recorded in 2012 , which was accompanied by a distinct drought, slightly lower grain yield, smaller mass of 1000 seeds which resulted in a higher share of nucleus,

4. OS-H-4 and OS-H- 6 are stable, widely adaptable hybrids. These hybrids, in improved production conditions (higher investment), will respond with significant increase in oil yield regardless on the environment,

5. OS-H-5 is a hybrid adapted to low yielding, and OS-H-7 to high yielding environments,

6. The hybrid OS-H-4, with respect to the achieved results of grain yield (6.257 t/ha), oil content $(51.62 \%)$ and oil yield $(2.944 \mathrm{t} / \mathrm{ha})$ can be considered a perspective hybrid for recognition and commercial production. 


\section{REFERENCES}

Balalić, I., Crnobarac, J., Dušanić, N. (2007). Planting date effects on oil yield in sunflower (Helianthus annuus L.). Helia. 30, 47: 153-158.

Balalić, I., Miklič, V., Jocić, S., Hladni, N., Marinković, R., Gvozdenović, S. (2008): Rezultati mikroogleda NS hibrida suncokreta i preporuka sortimenta za 2008. godinu. Zbornik radova, Institut za ratarstvo i povrtarstvo, Novi Sad, 45(II): 111 123.

Becker, H.C., Leon, J. (1988). Stability Analysis in Plant Breeding. Plant Breeding. 101: 1- 23.

Bošnjak, Đ. (1999). Navodnjavanje poljoprivrednih useva. Univerzitet u Novom Sadu, Poljoprivredni fakultet Novi Sad.

FAOSTAT Database. 2016. http://faostat.fao.org/site/567/DesktopDefault.aspx?PageID= 567\#ancor

Gadžo, D., Đikić, M., Mijić, A. (2011). Industrijsko bilje. Poljoprivredno- prehrambeni fakultet Sarajevo. 12-31.

Gotar, A.A., Berger, M., Labalette, F., Centis, S., Dayde, J., Calmon, A. (2008). Estimation of breeding potential for tocopherols and phytosterols in sunflower. In: Proc. of the 17th International Sunflower Conference, Cordoba, Spain. 555559.

Jocković, M., Prodanović, S., Jocić, S., Marinković, R., Marjanović Jeromela, A., Jocković, B., Čanak, P. (2014). Genne Effects and Combining Abilities for Oil Content in Sunflower. Journal on Field and Vegetable Crops Research. 51 (2): 106-109.

Josipović, M., Mađar, S. (2004). Proizvodnja suncokreta u uvjetima natapanja u redovnoj i postrnoj sjetvi. In Suncokret Helianthus annuus L. Vratarić (ed.). Poljoprivredni institut Osijek. Hrvatska. 245-258.

Kaya, M.D., Kolsarici, O. (2011). Seed yield and oil content of some sunflower (Helianthus annuus L.) hybrids irrigated at different growth stages. African J. Biotehnol. 10(22): 4591-4595.

Kaya Y. (2016). Sunflower. In: S.K. Gupta (Ed), Breeding Oil Seed Crops for Sustainable Production. Opportunities and Constraints Academic Press, Elsevier Inc, USA, 55-88.

Krizmanić, M., Liović, I., Mijić, A., Krizmanić, G., Šimić, B., Duvnjak, T., Bilandžić, M., Marinković, R., Gadžo, D., Markulj, A. (2012). Utjecaj okolina na kvantitativna svojstva novih OS-hibrida suncokreta. Sjemenarstvo. 29, 3-4: 121 135.

Krizmanić, M., Mijić, A., Liović, I., Sudarić, A., Sudar, R., Duvnjak, T., Krizmanić, G., Bilandžić, M. (2013). Utjecaj okoline na sadržaj ulja i sastav masnih kiselina kod novih OS-hibridnih kombinacija suncokreta. Poljoprivreda. 19, 1: 41-47.

Liović, I., Kovačević, V., Krizmanić, M., Mijić, A., Šimić, B. (2006). Precipitation influence on edible oil production from sunflower crop in Croatia. Cereal Research Communications. 34, 1: 573-576.

Miklič, V., Škorić, D., Balalić, I., Jocić, S., Jovanović, D., Hladni, N., Marinković, R., Joksimović, J., Gvozdenović, S. (2007). Rezultati ispitivanja NS hibrida suncokreta u ogledima i preporuka za setvu u 2007. godini. Zbornik radova Instituta za ratarstvo i povrtarstvo. 43, 1: 115-128.

Miklič, V., Balalić, I., Jocić, S., Marinković, R., Cvejić, S., Miladinović, D., Jocković, M., Hladni, N. (2014). Rezultati ispitivanja NS hibrida suncokreta u 
mikroogledima i preporuka za setvu u 2014. godini. Zbornik referata sa 48 . savetovanja agronoma Srbije, Zlatibor. 4-24.

Mijić, A., Sudarić, A., Krizmanić, M., Dunnjak, T., Bilandžić, M., Zdunić, Z., Ismić E. (2011). Grain and Oil Yield of Single-Cross and Three-Way Cross OS Sunflower Hybrids. Poljoprivreda. 1: 3-8.

Patel, M.D., Thompson, P.D. (2006): Phytosterols and vascular disease. Atherosclerosis. 186, 1: 12-9.

Pepó, P., Molnárová, J. (2010). Sustainable, environmental friendly field crops production in changing climate conditions (monograph), (Ed.: J. Molnárová, P. Pepó). Slovak University of Agriculture of Nitra. 191.

Piepho, H.P. (1999). Stability analysis using the SAS System. Agronomy Journal. 91: 154- 160.

Puškadija, Z., Mijić, A., Zdunić, Z., Gadžo, D., Štefanić, E., Đikić, M., Opačak, A., Florijančić, T. (2009). Utjecaj oprašivanja medonosnom pčelom (Apis melifera carnica L.) na agronomska svojstva suncokreta. Radovi Poljoprivrednog fakulteta Univerziteta u Sarajevu. 59, 2: 181-187.

Sudarić, A., Vratarić, M. (2001). Stabilnost i adaptabilnost nekoliko OS- kultivara soje u urodu zrna. Poljoprivreda. 7, 1: 18- 24.

Škorić, D. (2009). Sunflower breeding for resistance to abiotic stresses. Helia 32, 50: 116.

Škorić, D. (2012). Sunflower breeding. In Sunflower Genetics and Breeding. D. Škorić, Z. Sakač (ed.), International Monography, 165-354.

Vranceanu, A.V. (1977). Sunflower. Edicions Mudi Presa.

Waghchoure, E.S., Rana, M.A. (1988). Effect of honeybee pollination on seed setting, yield and oil content of sunflower (Helianthus annuus L.). In Proc. 12th Int. Sunflower Conf., Novi Sad, Yugoslavia. Int. Sunflower Assoc., Paris, France. 439- 440. 